\title{
KAJIAN KENYAMANAN JALUR PEJALAN KAKI DI JALAN TAMAN MINI 1 DAN JALAN RAYA PONDOK GEDE, JAKARTA TIMUR
}

\author{
Sintia Dewi Wulanningrum ${ }^{1}$
}

${ }^{1}$ Prodi S1 Arsitektur, Jurusan Arsitektur dan Perencanaan, Fakultas Teknik, Universitas Tarumanagara, Jakarta Surel:sintiaw@untar.ac.id

\begin{abstract}
ABSTRAK
Jalur pejalan kaki yang nyaman merupakan aspek penting dalam mendukung Transit Oriented Development atau TOD. TOD merupakan salah satu pendekatan pengembangan kota yang mengadopsi tata ruang campuran dan mengoptimalkan penggunaan angkutan massal seperti Trans Jakarta, Mass Rapid Transit (MRT), Light Rapid Transit (LRT), serta dilengkapi jaringan pejalan kaki atau jalur sepeda. Salah satu jalur pejalan kaki yang berada di dekat halte Trans Jakarta serta stasiun LRT adalah Jalur pejalan kaki di Jalan Taman Mini 1 dan Jalan Raya Pondok Gede, Kelurahan Pinang Ranti, Jakarta Timur. Akan tetapi, eksisting jalur pejalan kaki di Jalan Taman Mini 1 dan di Jalan Pondok Gede masih kurang nyaman, seperti; kondisi jalur pejalan kaki yang berlubang, tidak adanya penanda bagi disabilitas, selokan yang berbatasan langsung dengan jalur pejalan kaki sangat dalam dan terbuka, kurangnya tempat sampah, tidak adanya jembatan penyebrangan serta zebra cross dari shelter Trans Jakarta Garuda Tamini menuju keluar shelter, sehingga sangat berbahaya bagi pejalan kaki yang akan menyebrang. Metode penelitian yang digunakan yaitu kualitatif. Tujuan penelitian yaitu untuk mengidentifikasi jalur pejalan kaki di Jalan Taman Mini dan Jalan Raya Pondok Gede, serta merencanakan konsep jalur pejalan kaki yang aman dan nyaman untuk mendukung TOD di kawasan Taman Mini. Hasil penelitian menunjukkan bahwa jalur pejalan kaki masih kurang nyaman, terdapat paving blok yang berlubang, kurangnya street furniture seperti; tidak adanya guiding block,stepping stone, bangku taman, kurangnya tempat sampah dan signages.
\end{abstract}

Kata Kunci: kenyamanan, jalur pejalan kaki, TOD

\section{ABSTRACT}

Convenient pedestrian path is an important aspect to supporting Transit Oriented Development or TOD. TOD is a city development approach that adopts mixed spatial planning and optimizes the use of mass transportation, such as; the Trans Jakarta, Mass Rapid Transit (MRT), Light Rapid Transit (LRT), and equipped with a pedestrian or bicycle network. One of the pedestrian paths that is near the Trans Jakarta stop and LRT stations is the pedestrian route on Jalan Taman Mini 1 and Jalan Raya Pondok Gede, Kelurahan Pinang Ranti, East Jakarta. However, the existing pedestrian paths on Jalan Taman Mini 1 and Jalan Pondok Gede are still less comfortable, such as; the condition of the perforated pedestrian paths, no markers for disabilities, the ditch directly adjacent to the deepest and open pedestrian path, the lack of trash bins, the absence of a pedestrian bridge and a zebra crossing from the Garuda Tamini Trans Jakarta shelter to exit the shelter, making it very dangerous for pedestrians who will be crossing. The research objectives are to identify pedestrian paths on Taman Mini and Raya Pondok Gede Street, and safety planning and comfortable walking paths to support TOD in the Taman Mini area. The results showed that the pedestrian path was still not comfortable, there were paving blocks with holes, lack of street furniture such as; absence of guide beams, stepping stones, park benches, less bins and signs.

Keywords: convenience, pedestrian path, TOD 


\section{PENDAHULUAN}

Kawasan pusat kota memiliki karakteristik utama di mana terdapat kegiatan yang kompleks dan beragam serta kegiatan atau fungsi kawasan yang memiliki nilai sosial ekonomi yang sangat tinggi sekaligus merupakan tempat berkumpul orang dengan jumlah yang besar di dalam melakukan suatu kegiatan (Pawitro, 2015). Penyediaan jalur pejalan kaki di Indonesia telah tertera dalam UU No 26 Tahun 2007 tentang Penataan Ruang dan UU No. 22 Tahun 2009 tentang Jalan. Pada UU No. 26 Tahun 2007, ketentuan rencana penyediaan dan pemanfaatan prasarana dan sarana jaringan pejalan kaki harus disediakan dalam perencanaan kota. Dalam UU No. 22 Tahun 2009 menyatakan bahwa setiap jalan yang digunakan untuk lalu lintas umum, wajib dilengkapi dengan perlengkapan jalan, termasuk fasilitas bagi pejalan kaki.

Jalur pejalan kaki yang nyaman merupakan aspek penting dalam mendukung TOD (Transit Oriented Development). TOD merupakan salah satu pendekatan pengembangan kota yang mengadopsi tata ruang campuran dan mengoptimalkan penggunaan angkutan massal, seperti Trans Jakarta (BRT), MRT, LRT, serta dilengkapi jaringan pejalan kaki atau jalur sepeda. Salah satu jalur pejalan kaki yang berada di dekat halte Trans Jakarta serta stasiun LRT adalah Jalur pejalan kaki di Jalan Taman Mini 1 dan di Jalan Raya Pondok Gede, Jakarta Timur. Jalur pejalan kaki di Jalan Taman Mini I merupakan salah satu jalur pejalan kaki menuju ke Kawasan Taman Mini, yang dipakai pejalan kaki untuk berpindah dari satu tempat ke tempat yang lain. Bangunan atau tempat penting yang berada di kawasan tersebut antara lain; Taman Mini Indonesia Indah, Taman Mini Square, Teras Taman Mini, Masjid At Tin, Terminal Pinang Ranti, Stasiun LRT Taman Mini, Rumah Sakit Moh. Ridwan Meuraksa dan lain sebagainya.

Menurut Carr, Stephen, et. All (1992) jalur pejalan kaki merupakan bagian dari kota, dimana orang bergerak dengan kaki, biasanya disepanjang sisi jalan yang direncanakan atau terbentuk dengan sendirinya yang menghubungkan satu tempat dengan tempat lainnya. Selain itu, menurut Ramadhan (2018) jalur pejalan kaki adalah area berupa jalur yang digunakan oleh pejalan kaki sebagai penghubung dalam melakukan suatu aktivitas di suatu lokasi.

Berdasarkan Permen PU (2014), perhitungan dimensi tubuh manusia, kebutuhan ruang minimum pejalan kaki:

1) tanpa membawa barang dan keadaan diam yaitu $0,27 \mathrm{~m} 2$;

2) tanpa membawa barang dan keadaan bergerak yaitu $1,08 \mathrm{~m} 2$; dan

3) membawa barang dan keadaan bergerak yaitu antara 1,35 m2 -1,62 m2

Persyaratan ruang jalur pejalan kaki berkebutuhan khusus, berdasarkan PU (2014) antara lain:

1) jalur pejalan kaki memiliki lebar minimum 1.5 meter dan luas minimum $2,25 \mathrm{~m} 2$;

2) alinemen jalan dan kelandaian jalan mudah dikenali oleh pejalan kaki antara lain melalui penggunaan material khusus;

3) menghindari berbagai bahaya yang berpotensi mengancam keselamatan seperti jeruji $\mathrm{d}$ an lubang;

4) tingkat trotoar harus dapat memudahkan dalam menyeberang jalan;

5) dilengkapi jalur pemandu dan perangkat pemandu untuk menunjukkan berbagai perubahan dalam tekstur trotoar;

6) permukaan jalan tidak licin;

7) Jalur pejalan kaki dengan ketentuan kelandaian yaitu sebagai berikut: a) tingkat kelandaian tidak melebihi dari 8\% (1 banding 12); b) jalur yang landai harus memiliki pegangan tangan setidaknya untuk satu sisi (disarankan untuk kedua sisi). Pada akhir landai setidaknya panjang pegangan tangan mempunyai kelebihan sekitar 0,3 meter; c) pegangan tangan harus dibuat dengan ketinggian 0.8 meter 
diukur dari permukaan tanah dan panjangnya harus melebihi anak tangga terakhir; d) seluruh pegangan tangan tidak diwajibkan memiliki permukaan yang licin; dan e) area landai harus memiliki penerangan yang cukup.

Perabot jalan atau Street Furniture adalah benda dan peralatan yang dipasang di sepanjang jalan untuk berbagai keperluan seperti, bangku-bangku, penghalang lalu lintas, tempat sampah, kotak pos, kotak telepon, lampu jalan, lampu lalu lintas, rambu lalu lintas, halte dan lain-lain, yang ditempatkan secara kolektif pada suatu lansekap jalan untuk kenyamanan, kesenangan, informasi, kontrol sirkulasi, perlindungan dan kenikmatan pengguna jalan. Street Furniture harus menyatu dengan lingkungan sekitar. Bahan yang digunakan dalam street furniture yaitu bahan yang mudah didapat, kuat terhadap cuaca, mudah dalam perawatan, mudah dalam perbaikan, kuat dan aman bagi penguna jalan maupun lingkungan sekitarnya (Harris \& Dines, 1988). Keamaanan merupakan kondisi dimana seseorang terlindungi dari ancaman atau bahaya yang mengancam keselamatan jiwanya. Keamanan juga bisa berarti kondisi sesorang merasa aman ketika melakuakan aktifitas (Nur, 2015).

Kondisi eksisting jalur pejalan kaki di Jalan Taman Mini 1 dan di Jalan Raya Pondok Gede masih kurang nyaman, seperti; kondisi jalur pejalan kaki yang berlubang, tidak adanya penanda bagi disabilitas, selokan yang berbatasan langsung dengan jalur pejalan kaki sangat dalam dan terbuka, kurangnya tempat sampah, tidak adanya jembatan penyebrangan serta zebra cross dari shelter Trans Jakarta Garuda Tamini menuju keluar shelter, sehingga sangat berbahaya bagi pejalan kaki yang akan menyebrang. Dengan adanya pembangunan stasiun MRT Taman Mini, hendaknya diikuti dengan ikut meningkatnya kenyamanan jalur pejalan kaki disekitar kawasan, karena jalur pejalan kaki ini merupakan aspek penting untuk mendukung TOD Kawasan Taman Mini, akan tetapi keberadaan jalur pejalan kaki serta fasilitas penunjangnya masih kurang diperhatikkan.

\section{Tujuan penelitian}

-Mengidentifikasi jalur pejalan kaki di Jalan Taman Mini dan Jalan Raya Pondok Gede.

-Merencanakan konsep jalur pejalan kaki yang aman dan nyaman untuk mendukung TOD di kawasan Taman Mini.

\section{METODE PENELITIAN}

Metode penelitian dengan menggunakan metode kualitatif, untuk menganalisis eksisting jalur pejalan kaki berdasarkan kajian teori, serta menganalisa konsep jalur pejalan kaki yang nyaman untuk mendukung TOD di kawasan tersebut.Teknik pengumpulan data primer diperoleh melalui observasi atau pengamatan pada jalur pejalan kaki di Jalan Taman Mini 1 dan Jalan Raya Pondok Gede, Jakarta Timur. Sedangkan pengumpulan data sekunder, melalui studi literatur yang berasal dari buku, jurnal serta peraturan yang terkait dengan jalur pejalan kaki.

Lokasi penelitian berada di Kawasan Taman Mini Square, tepatnya di Jalan Taman Mini I dan Jalan Pondok Gede, Kelurahan Pinang Ranti, Kecamatan Makasar. Radius penelitian 400 m2, sesuai dengan radius pelayanan TOD . Jalur pejalan kaki yang diteliti, dibagi menjadi 4 jalur yaitu jalur 1 berada di jalan Taman Mini I, jalur 2 berada di seberang jalan Taman Mini didepan LRT Taman Mini, jalur 3 berada di jalan Raya Pondok Gede dan jalur 4 berada di Jalan Raya Pondok Gede 1 (depan Masjid Uswatun Hasanah). 


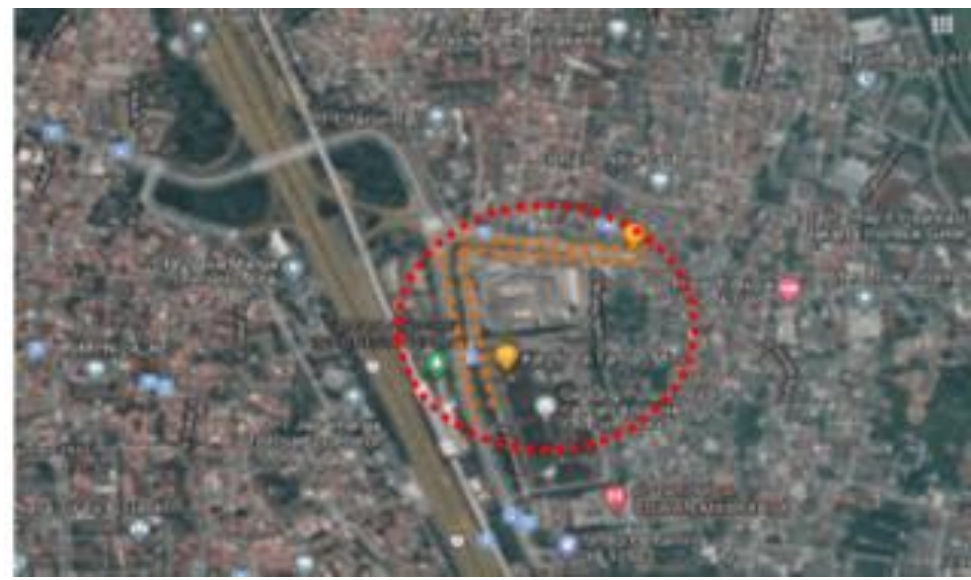

Gambar 1. Peta Lokasi Penelitian

Sumber : Google map, 2020

\section{HASIL DAN PEMBAHASAN}

Radius Jalur pejalan kaki yang diteliti adalah 400-800 meter sesuai dengan radius kenyamanan jalur pejalan kaki pada Transit Oriented Development (TOD). Lokasi penelitian dibagi menjadi 4 jalur, jalur 1 dan 2 berada di Jalan Tamini 1 dan, Jalur 3 dan 4 berada di Jalan Raya Pondok Gede (gambar 2).
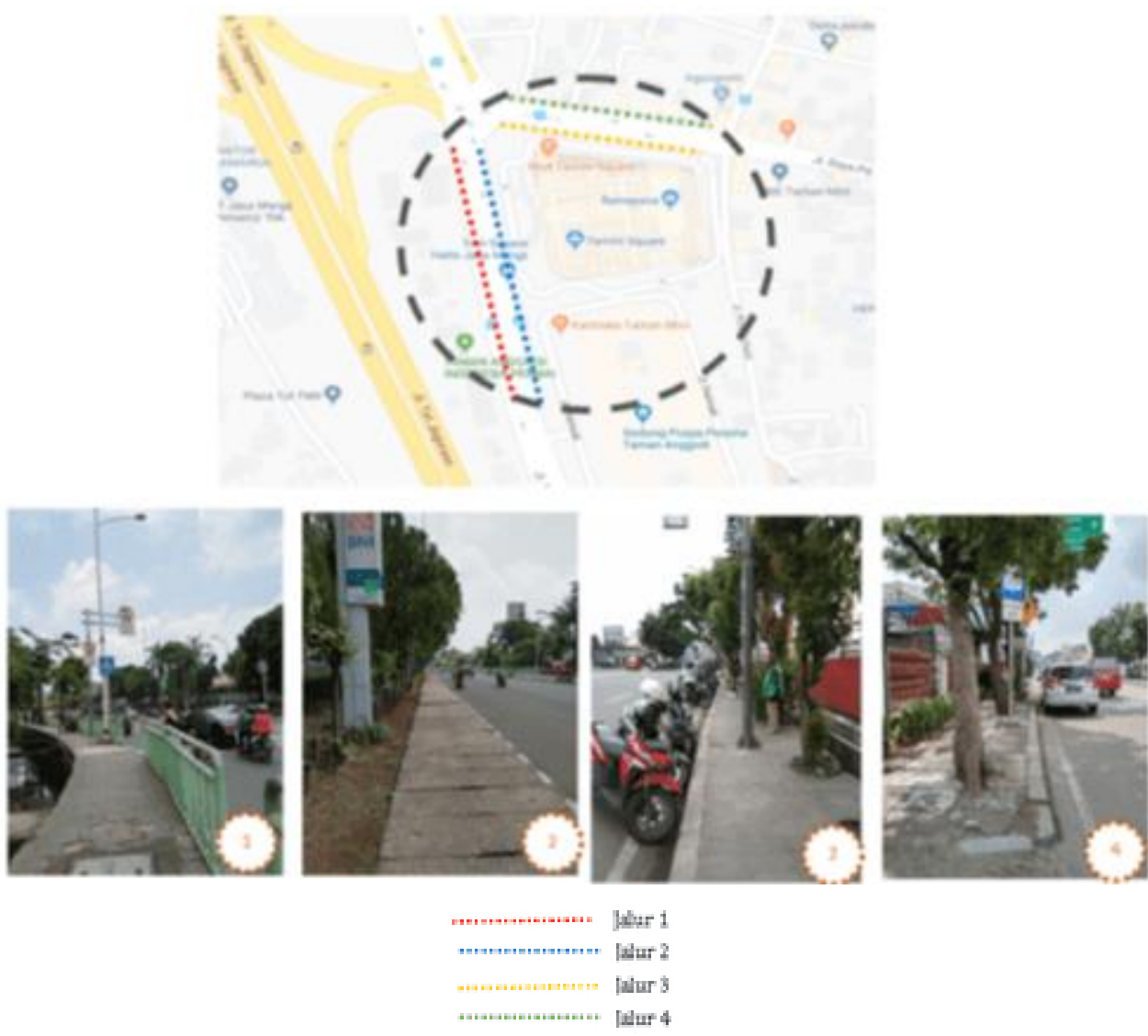

Gambar 2. Deliniasi Lokasi Penelitian

Sumber : Google map dan Penulis, 2020 


\section{a. Pembahasan Jalur 1}

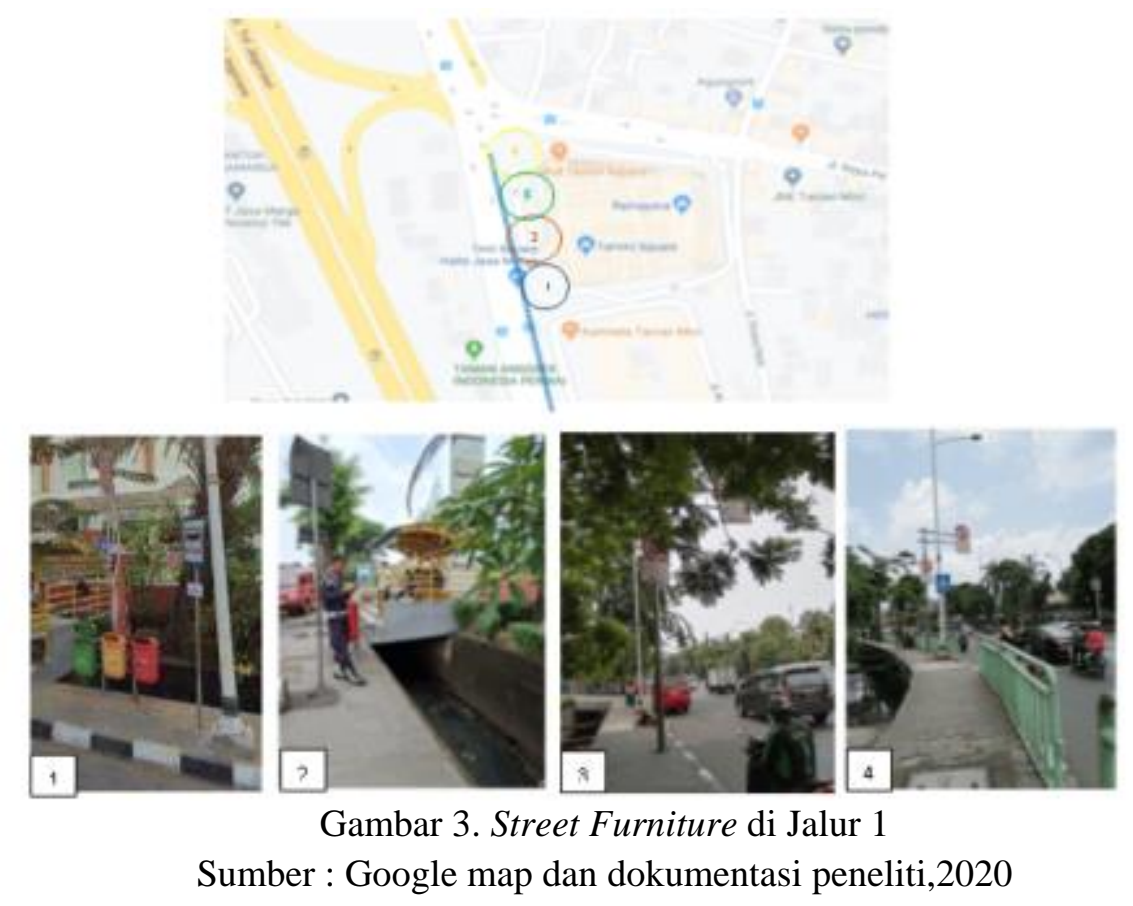

Jalur pejalan kaki berada di sisi barat Tamini Square, tepatnya berada di depan Tamini Square. Street Furniture yang berada di Jalan Taman Mini 1 antara lain; tempat sampah, halte taman mini, lampu taman dan signages (berupa tanda dilarang berhenti, tanda pemberhentian bus).

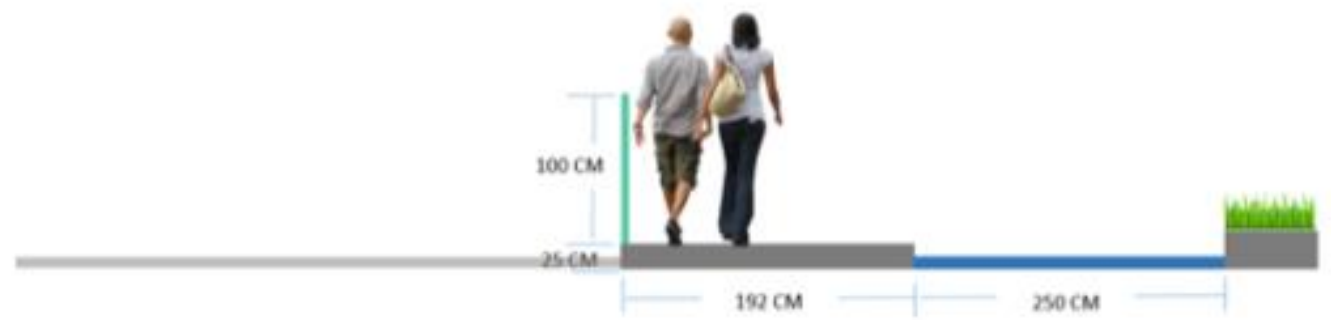

Gambar 4. Potongan Eksisting di Jalur 1

Sumber : Peneliti,2020

Pada jalur 1 lebar jalur pejalan kaki $192 \mathrm{~cm}$, sudah sesuai standart minimal yaitu saat membawa barang dan keadaan bergerak antara 1,35 m2 -1,62 m2 (PU, 2014), namun belum ada guiding block untuk disabilitas, tidak ada pembatas antara selokan. Selain itu, kedalaman selokan air sekitar 1,5 meter juga semakin menambah masalah ketidakamanan bagi pejalan kaki. Oleh sebab itu, diperlukan penutup pada selokan air, dengan jalur pejalan kaki, serta tidak terdapat Pelican Crossing yang digunakan sebagai lampu khusus pejalan kaki ketika akan menyebrang).Selain itu, shelter pejalan kaki hanya ada 1 shelter (gambar 3), sarana penunjang pejalan kaki juga masih minim pada jalur 1, hanya terdapat 1 tempat sampah, signanges, lampu jalan. Oleh sebab itu diperlukan penataan fasilitas penunjang pejalan kaki antara lain penambahan guiding block, pelican crossing, lampu taman, penutup selokan serta bangku taman. 


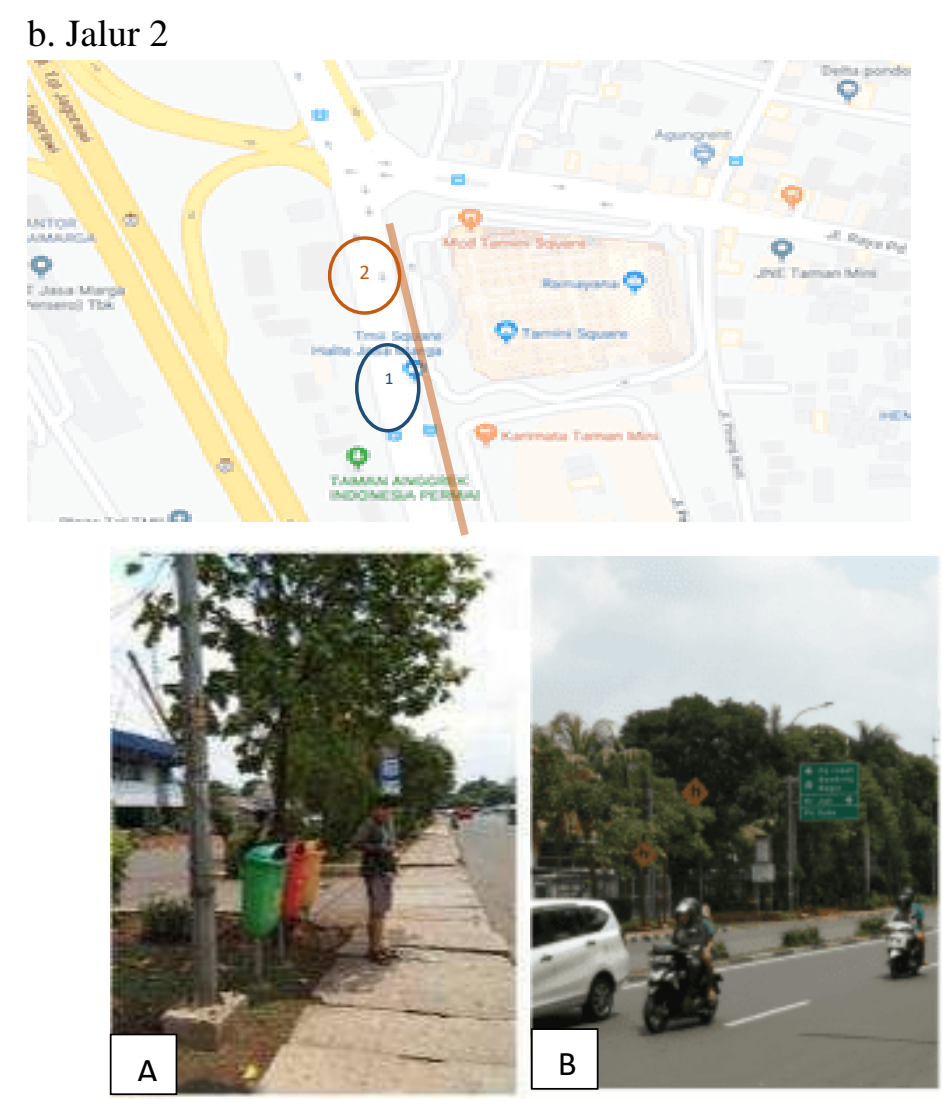

Gambar 5.Street Furniture di Jalur 2

Sumber : Google map dan dokumentasi peneliti,2020

Street furniture pada eksisting jalur pejalan kaki 2 berupa tempat sampah (gambar A), lampu jalan (gambar B) dan signages (berupa jalur pemberhentikan Jaklingko, penanda jalur penyebrang untuk pejalan kaki dan penanda jalan menuju Bogor, Pondok Indah).

Pada eksisting jalur 2, kondisi jalur pejalan kaki cukup baik, terdapat blok beton, dengan bagian tengah dilubangi untuk memasukkan air hujan ke dalam selokan, serta pada sisi barat jalur pejalan kaki terdapat ruang terbuka yang ditanami tanaman hias, meskipun pemanfaatnya masih kurang optimal.

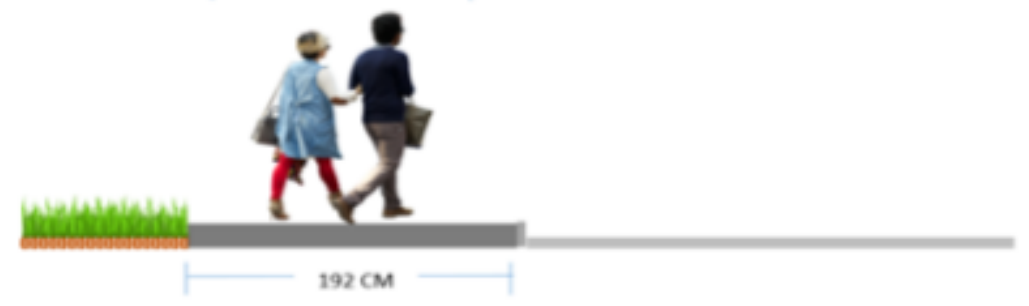

Gambar 6. Potongan Eksisting di Jalur 2

Sumber : Peneliti,2020

Pada jalur pejalan kaki 2, street furniture masih kurang, hanya terdapat satu tempat sampah yang berada di depan pintu masuk kantor Jasa Marga. Sebagai jalur pejalan kaki utama yang akan digunakan pejalan kaki keluar masuk ke LRT Taman Mini, kondisinya masih kurang nyaman antara lain; tidak terdapat shelter, bangku taman, penyebrangan hanya berupa Zebra Cross untuk menuju sisi kanan ( Taman Mini Square), tidak adanya penanda bagi disabilitas. 


\section{c. Jalur 3}
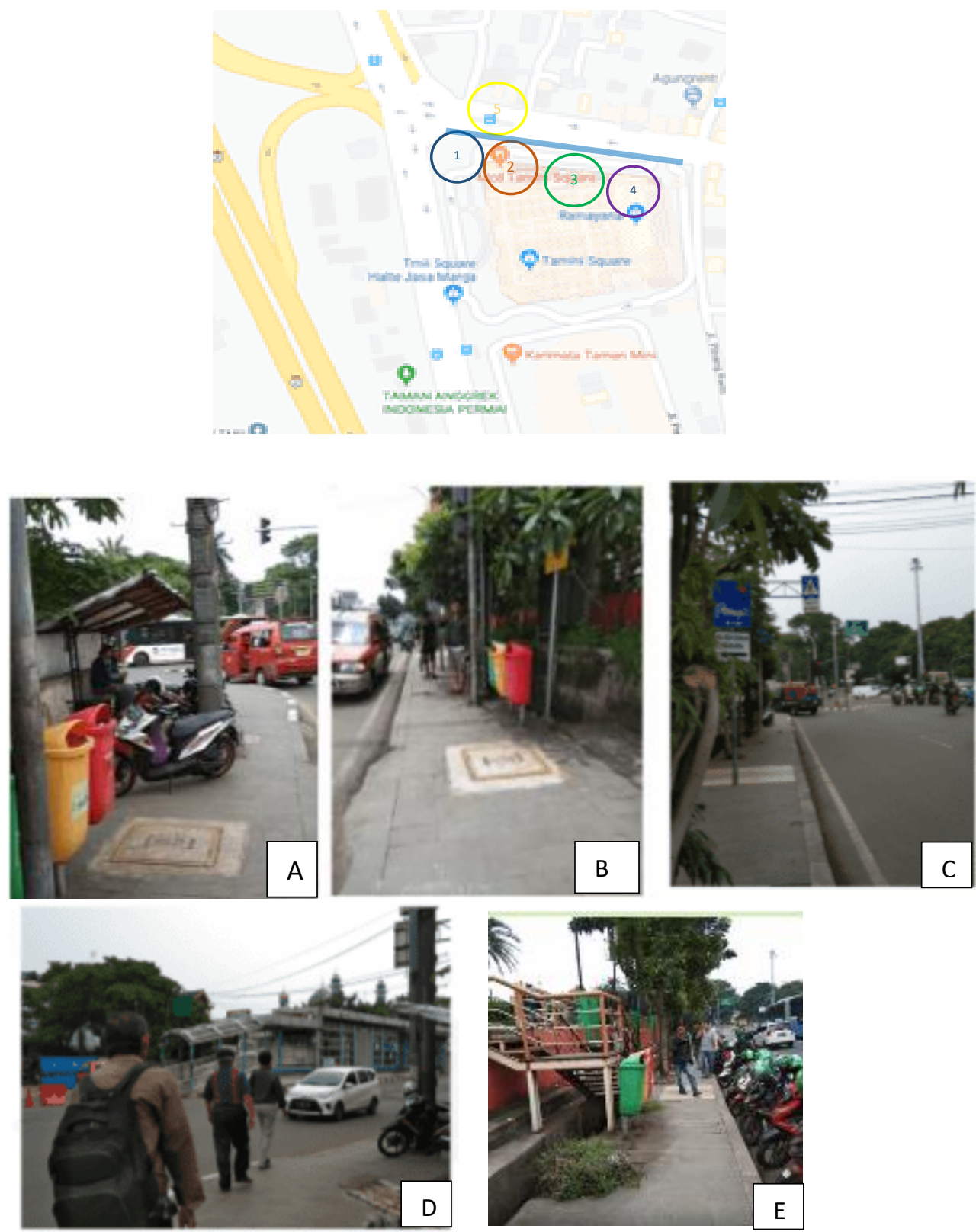

Gambar 7. Street Furniture di Jalur 3

Sumber : Google map dan dokumentasi peneliti,2020

Street furniture berupa shelter untuk tempat beristirahat ojek pangkalan (gambar A), tempat sampah (gambar Bdan E), halte Trans Jakarta Garda Tamini (gambar D), serta Signages (gambar C) berupa tanda menyebrang jalan untuk pejalan kaki dan petunjuk arah menuju fasilitas sekitar. 


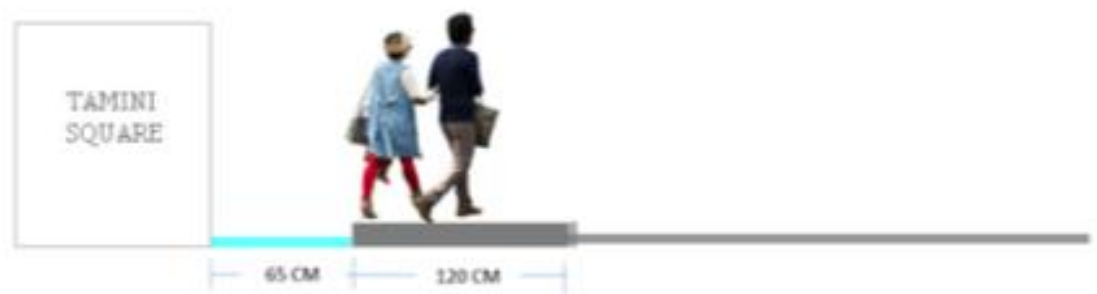

Gambar 8. Potongan di Jalur 3

Sumber : Peneliti,2020

Jalur 3 berbatasan langsung dengan Tamini Square, dan lebar jalur pejalan kaki jalur 3 yaitu $120 \mathrm{~cm}$, belum memenuhi standart yang ditetapkan PU , yaitu membawa barang dan keadaan bergerak yaitu antara 1,35 m2 -1,62 m2. Selain itu, jika untuk jalur pejalan kaki berkebutuhan khusus, masih kurang dari standart, karena standart minimum menurut PU (2014) memiliki lebar minimum 1.5 meter dan luas minimum 2,25 m2. Fasilitas penunjang pada jalur ini juga masih minim, tidak ada shelter, pelican crossing, kurangnya tempat sampah dan signages.

\section{d. Jalur 4}

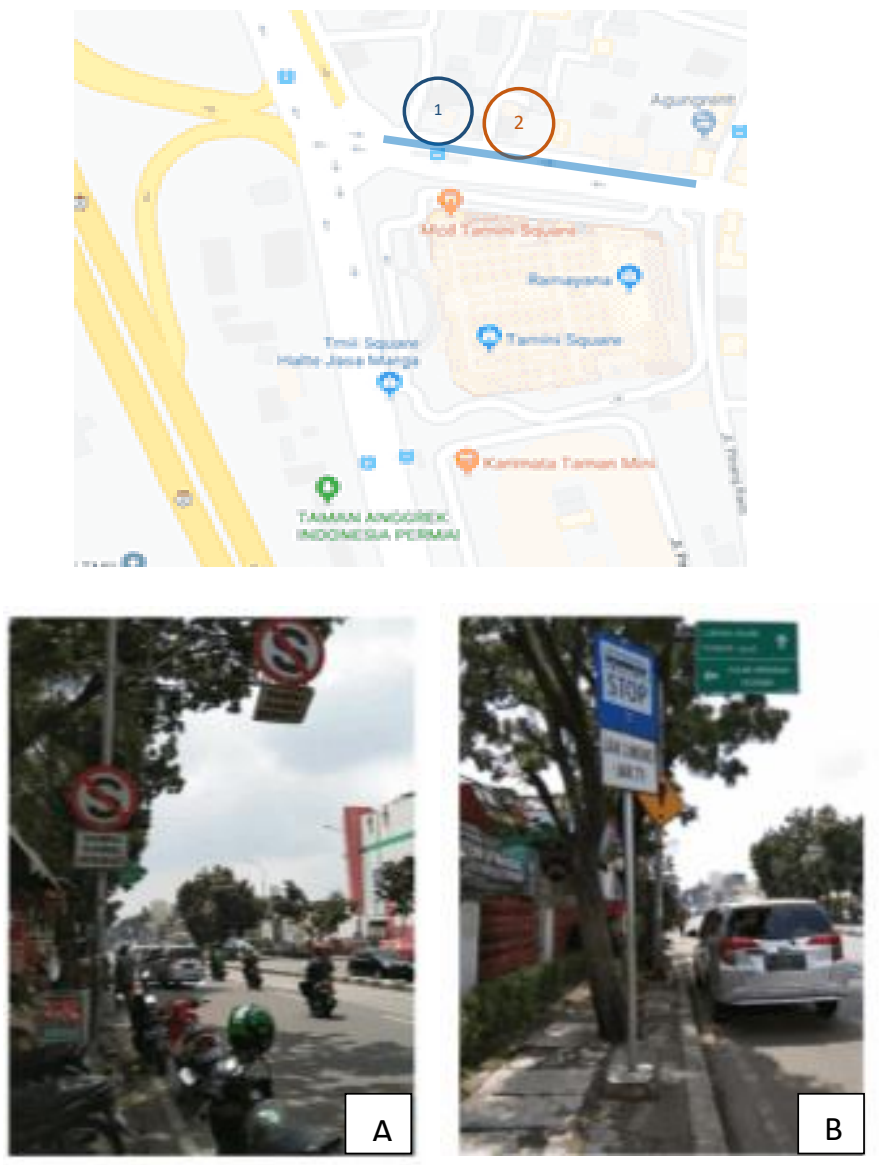

Gambar 9. Street Furniture di Jalur 4

Sumber : Google map dan dokumentasi peneliti,2020 
Pada Jalur 4 tidak terdapat Street furniture, karena sebagian besar jalur pejalan kaki digunakan warga untuk berdagang seperti berdagang buah, nasi, pulsa dan lain sebagainya. Signages pada jalur ini antara lain tanda dilarang berhenti dan tanda pemberhentiaan Jaklingko (gambar B).

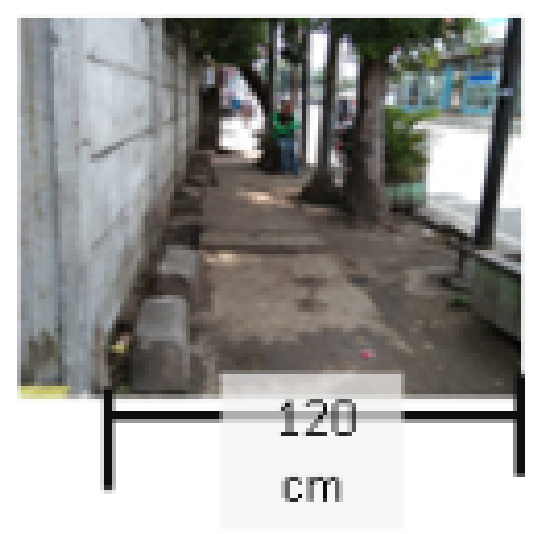

Gambar 10. Eksisting Jalur 4

Sumber : Peneliti,2020

Lebar jalur pejalan kaki yaitu $120 \mathrm{~cm}$, sudah sesuai standart yaitu tanpa membawa barang dan keadaan bergerak yaitu 1,08 $\mathrm{m} 2$, tetapi jika untuk jalur pejalan kaki berkebutuhan khusus, masih kurang dari standart, karena standart minimum menurut PU (2014) memiliki lebar minimum 1.5 meter dan luas minimum 2,25 $\mathrm{m} 2$. Fasilitas penunjang pada jalur ini juga masih minim, tidak ada shelter, pelican crossing, kurangnya tempat sampah dan signages.

Berdasarkan analisis pada jalur 1, 2, 3 dan 4, maka diperlukan penataan terkait street furniture. Pada jalur 1, lebar jalur pejalan kaki sudah memenuhi standart minimum, akan tetapi fasilitas penunjang masih kurang ,seperti tidak ada guiding block, pelican crossing, kurangnya lampu taman, tidak adanya penutup selokan serta bangku taman, sehingga diperlukan penataan terkait pentaan street furniture. Pada jalur 2 , lebar jalur pejalan kaki sudah sesuai standart minimal, akan tetapi tidak terdapat shelter, bangku taman, penyebrangan hanya berupa Zebra Cross, tidak adanya penanda bagi disabilitas. Pada jalur 3, lebar jalur pejalan kaki kurang dari standart minimal yang ditentukan, untuk membawa barang dan keadaan bergerak yaitu antara 1,35 m2 -1,62 m2. Selain itu, untuk jalur pejalan kaki berkebutuhan khusus, masih kurang dari standart, karena standart minimum menurut PU (2014) memiliki lebar minimum 1.5 meter dan luas minimum 2,25 m2. Fasilitas penunjang pada jalur ini juga masih minim, tidak ada shelter, pelican crossing, kurangnya tempat sampah dan signages. Pada jalur 4, lebar jalur pejalan kaki, jika tidak membawa barang memenuhi standart minimal, yaitu 1,08 m2. Akan tetapi, fasilitas penunjang pada jalur ini juga masih minim, tidak ada pelican crossing, kurangnya tempat sampah dan kurangnya signages. Berdasarkan analisis terkait jalur 1,2,3 dan 4, maka diperlukan penataan terkait street furniture, seperti perencanaan guiding blok, pelican crossing, penambahan yempat sampah, lampu taman dan bangku taman.

Penaatan jalur 1 pada area halte, untuk meningkatkan kenyamanan pengguna jalan dilengkapi Pelican Crossing , Guiding Blok bagi penyandang disabilitas, bollard supaya pengguna kendaraan bermotor tidak naik ke atas trotoar serta penataan taman yang dilengkapi bangku taman. Untuk jalur pejalan kaki berupa Grass Blok supaya air hujan bisa meresap sehingga mengurangi terjadinya banjir. 


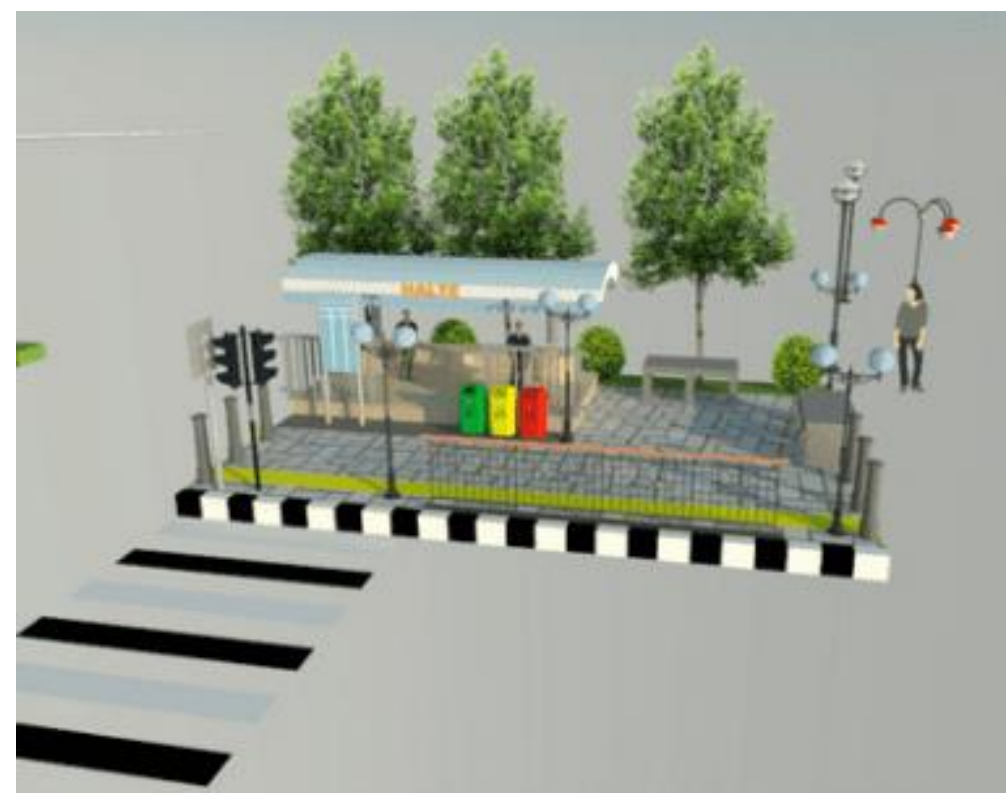

Gambar 11. Penataan Jalur 1 (Area 1)

Sumber : Penulis,2020

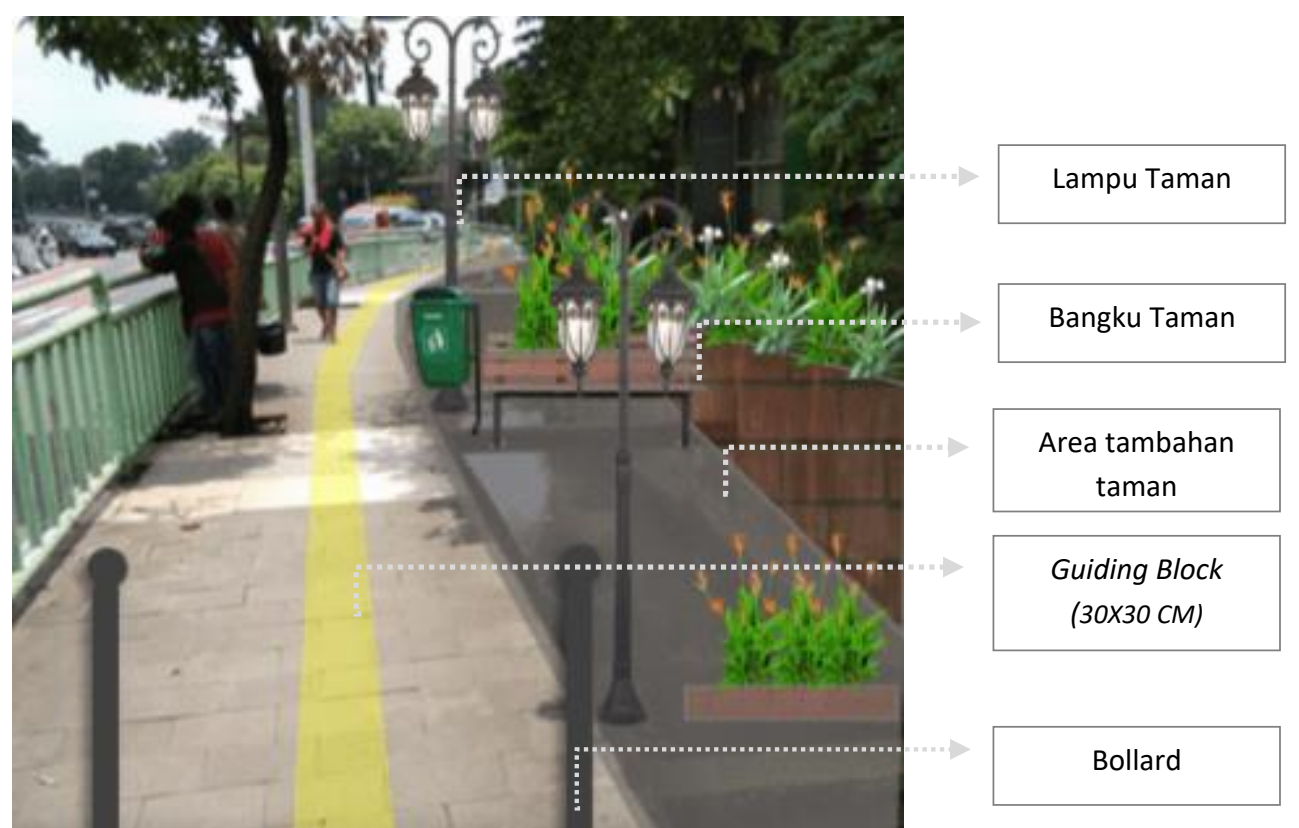

Gambar 12. Penataan Jalur 1 (Area 2)

Sumber : Penulis, 2020

Pada eksisting jalur 1, lebar jalur pejalan kaki adalah $192 \mathrm{~cm}$ sedangkan lebar taman adalah $300 \mathrm{~cm}$. Taman yang direncanakan, awalnya adalah selokan terbuka, oleh sebab itu pada penataan direncanakan selokkan tersebut ditutup dengan taman yang bisa dimanfaatkan pejalan kaki untuk beristirahat atau bersantai sejenak. Penataan jalur 1 area 2 , berupa penataan material penutup jalur pejalan kaki berupa Grass Block, penataan Guiding Blok, tempat sampah, taman yang dilengkapi dengan lampu taman serta bangku taman. Eksisting pohon perdu pada jalur dipertahankan, supaya kenyamanan pejalan kaki saat 
siang hari tetap terjaga. Selain itu, untuk membatasi antara jalan raya dengan jalur pejalan kaki dibuat pagar serta Bollard.

Penataan pada jalur 2 berupa penambahan Guiding Block, Pelican Crossing, shelter untuk menunggu angkutan umum serta dilengkapi dengan street furniture lainnya seperti lampu taman, tempat sampah dan bangku taman. Material penutup jalur pejalan adalah Grass Block, dengan lebar jalur $192 \mathrm{~cm}$ dan lebar $\operatorname{taman} 250 \mathrm{~cm}$.

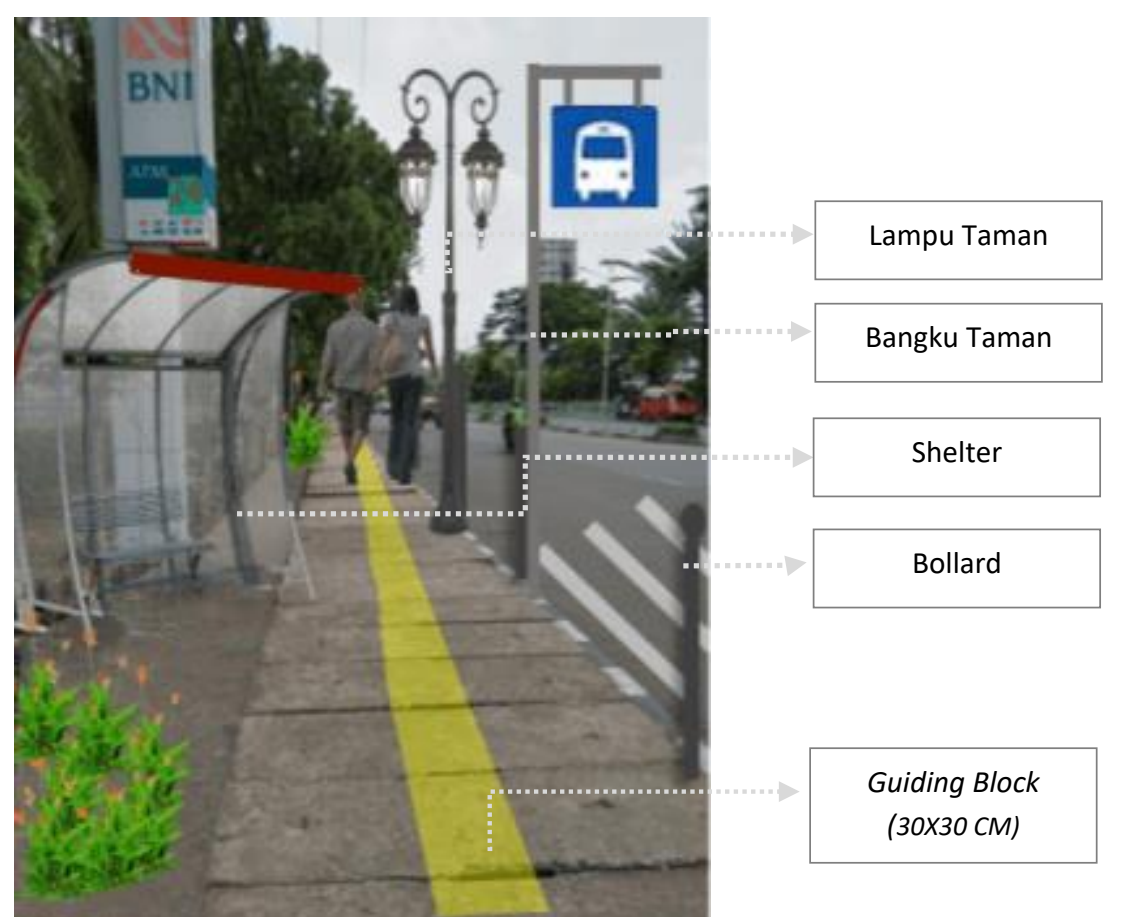

Gambar 13. Penataan Jalur 2

Sumber : Penulisi,2020

Lebar jalur pejalan kaki pada jalur 3 adalah $120 \mathrm{~cm}$, direncanakan adanya penambahan Guiding Blok dengan lebar $30 \mathrm{~cm}$, Pelican Crossing, shelter, tempat sampah dan bangku taman. Pada eksisting jalur 3 terdapat selokan dengan ukuran $65 \mathrm{~cm}$, selokan tersebut akan ditutup dengan taman yang bisa digunakan pengguna jalan untuk beristirahat sejenak. 


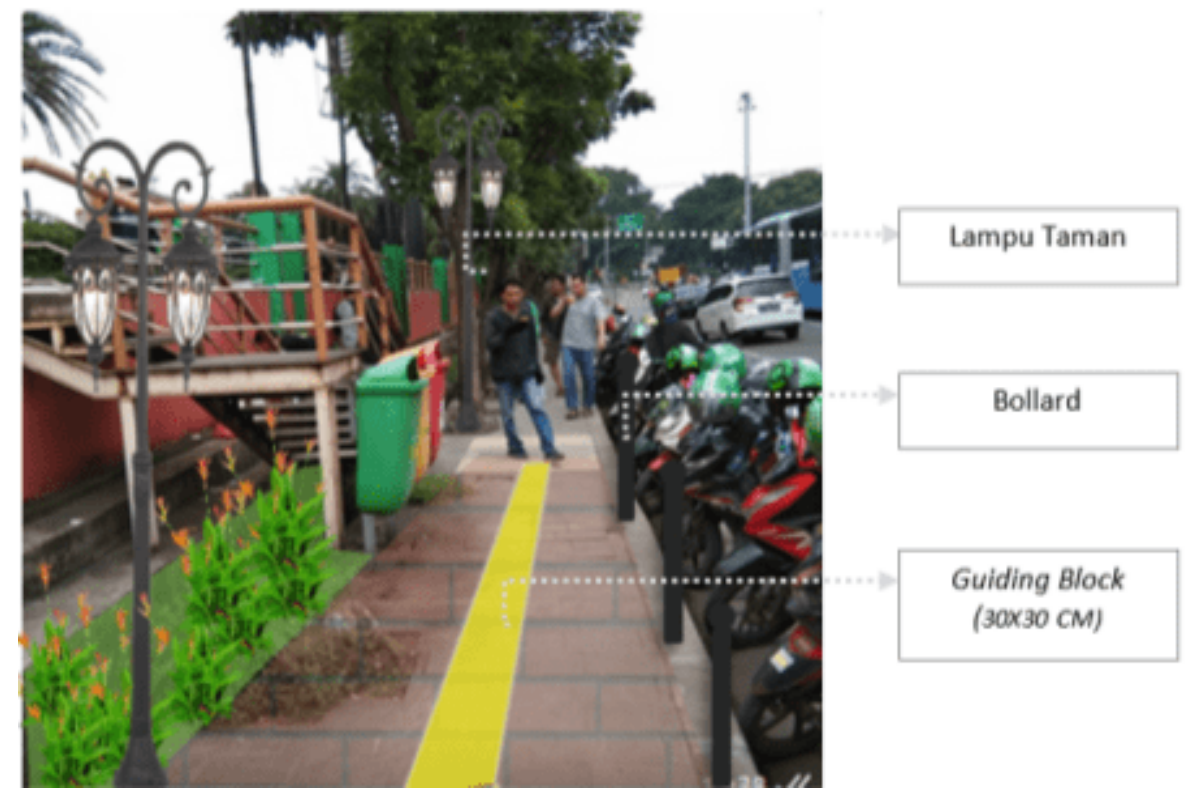

Gambar 14. Penataan Jalur 3

Sumber : Penulis, 2020

Pada jalur 4 , eksisting jalur pejalan kaki dipakai sebagai tempat berjualan warga, dikembalikan sesuai fungsinya yaitu jalur pejalan kaki, jalur pejalan kaki dilengkapi Guiding Blok (lebar 30 $\mathrm{cm})$, shelter untuk menunggu angkutan umum, bollard dan tempat sampah.

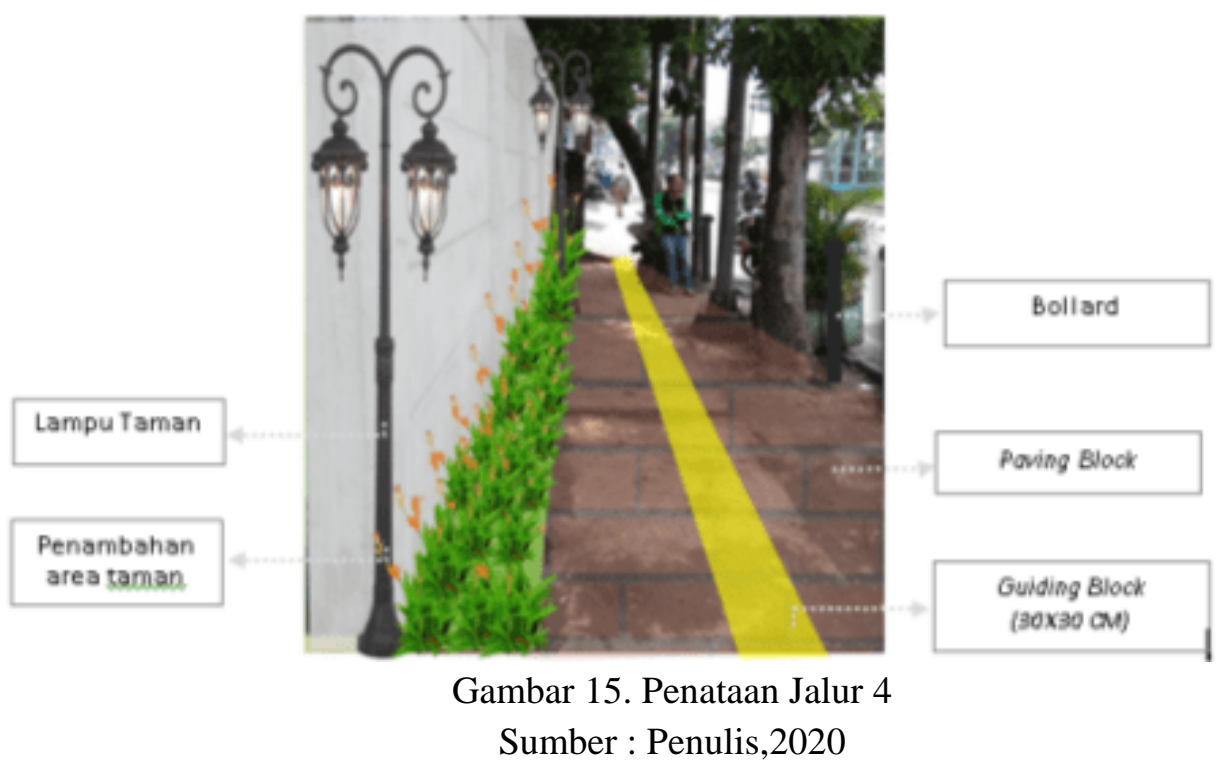

\section{KESIMPULAN}

Pada jalur pejalan kaki di Jalan Tamini 1 dan Jalan Raya Pondok Gede masih kurang nyaman. Pada jalur 1 lebar jalur pejalan kaki $192 \mathrm{~cm}$, sudah sesuai standart minimal yaitu saat membawa barang dan keadaan bergerak antara 1,35 m2 -1,62 m2 (PU, 2014), akan tetapi fasilitas penunjang masih kurang ,seperti tidak ada guiding block, pelican crossing, kurangnya lampu taman, tidak adanya penutup selokan serta bangku taman. Pada jalur 2 , lebar jalur pejalan kaki sudah sesuai standart minimal, akan tetapi tidak terdapat shelter, bangku taman, penyebrangan hanya berupa Zebra Cross, tidak adanya penanda bagi disabilitas. Pada jalur 3, lebar jalur pejalan kaki kurang dari standart minimal yang ditentukan , untuk membawa barang dan keadaan bergerak yaitu antara 1,35 m2 -1,62 m2. Selain itu, jika untuk jalur 
pejalan kaki berkebutuhan khusus, masih kurang dari standart, karena standart minimum menurut PU (2014) memiliki lebar minimum 1.5 meter dan luas minimum 2,25 m2. Fasilitas penunjang pada jalur ini juga masih minim, tidak ada shelter, pelican crossing, kurangnya tempat sampah dan signages. Pada jalur 4, lebar jalur pejalan kaki, jika tidak membawa barang memenuhi standart minimal, yaitu 1,08 m2. Akan tetapi, fasilitas penunjang pada jalur ini juga masih minim, tidak ada pelican crossing, kurangnya tempat sampah dan kurangnya signages. Berdasarkan analisis terkait jalur 1,2,3 dan 4, maka diperlukan penataan terkait street furniture, seperti perencanaan guiding blok, pelican crossing, penambahan yempat sampah, lampu taman, bollard dan bangku taman.

\section{Saran}

Diperlukan upaya penataan jalur pejalan kaki oleh pemerintah, supaya jalur pejalan kaki di Jalan Taman Mini 1 dan Jalan Raya Pondok Gede untuk meninggkatkan kenyamanan bagi pejalan kaki, sehingga dapat mengurangi penggunaan kendaraan pribadi dan berpindah pada transportasi umum, karena prasarana penunjang bagi pejalan kaki telah nyaman dan aman

\section{REFERENSI}

Harris, C., Dines, N. (1988). Time Saver Standar For landscape Architecture. MeGraw Hill Book Co, New York.

Nur, Z.A., Suwandono,D. (2015). Kajian Keamanan Jalur Pejalan Kaki Di Jalan Arteri Sekunder Berdasarkan Aspek Fisik Dan Masyarakat (Studi Kasus: Jalan Pemuda Kabupaten Klaten). Jurnal Ruang 1 (1), pp. 1-10. DOI: HTTP://DX.DOI.ORG/10.14710/RUANG.1.4.1-10

Pawitro, U. (2015). Peningkatan Aspek 'Keindahan Kota (The Urban Esthetic) di Kawasan Pusat Kota (Studi Kasus : Kawasan Pusat Kota Bandung - Jawa Barat). Jurnal Unsrat, 12 (2)..pp.1-16

Peraturan Menteri Pekerjaan Umum Nomor : 03/Prt/M/2014 /2011 Tentang Pedoman Perencanaan, Penyediaan, Dan Pemanfaatan Prasarana Dan Sarana Jaringan Pejalan Kaki Di Kawasan Perkotaan.

Ramadhan, M.A., Pratama,G.N.I.P., Hidayah, M. (2018). Penataan Sistem Jalur Pejalan Kaki Di Universitas Negeri Yogyakarta. Jurnal Inersia, XIV (1). pp. 101-117 DOI: https://doi.org/10.21831/inersia.v14i1.19498

Sthepen,C,et al. (1992). Public Space. Cambridge: Cambridge University Press

UU No. 22 Tahun 2009 tentang Jalan

UU No 26 Tahun 2007 tentang Penataan Ruang 
KAJIAN KENYAMANAN JALUR PEJALAN KAKI

DI JALAN TAMAN MINI 1 DAN JALAN RAYA PONDOK GEDE,

JAKARTA TIMUR 